\title{
Role of Procedural Justice, Organizational Commitment and Job Satisfaction on job Performance: The Mediating Effects of Organizational Citizenship Behavior
}

\author{
Achmad Sani ${ }^{1}$ \\ ${ }^{1}$ Department of Management, State Islamic University of Maulana Malik Ibrahim Malang, Indonesia \\ Correspondence: Achmad Sani, State Islamic University of Maulana Malik Ibrahim Malang, 65145, Indonesia. \\ E-mail: achmad_sani72@yahoo.com
}

Received: April 27, 2013

Accepted: May 15, 2013

Online Published: July 12, 2013

doi:10.5539/ijbm.v8n15p57

URL: http://dx.doi.org/10.5539/ijbm.v8n15p57

\begin{abstract}
The study examines the impact of procedural justice, organizational commitment, job satisfaction on employee performance, and the potential mediating role played by organization citizenship behaviors in that process. This model was tested using a sample of 70 employees embedded in 2 groups from 15 branches of a large, syariah bank in Malang. The sample is taken using proportional random sampling. Data is collected directly from respondents using questionnaires and technical data analysis using GeSCA.

The study results showed that both procedural justice and organizational commitment positively affected Organizational Citizenship Behavior. Organizational commitments do positive influence job performance. Job satisfaction did not positively influence Organizational Citizenship Behavior and job performance. Organizational Citizenship behavior positively influences job performance. Organizational Citizenship behavior acted as a partial mediator between procedural justice, organizational commitment, and job performance. A number of suggestions on managerial theory and implementation were proposed.
\end{abstract}

Keywords: banking employees, procedural justice, organizational commitment, job satisfaction, job performance, organizational citizenship behavior

\section{Introduction}

The emergence and development of the syariah banks began from the issuing of the October Policies which managed the deregulation of the banking industry in Indonesia. The emergence of syariah banks in Indonesia is an interesting phenomenon and is the highest point of the long effort by some individual (scholars and intellectuals) both individually and institutionally in the process of social transformation. In its development, then later all the Islamic Business Unit at Commercial Bank in accordance with the law - law number 23 year 2008, about Islamic banking must be changed to Islamic Banks. It is expected that at least within 15 years after the rule is applied, ie, in 2023, all UUS Banks must be Syari'ah (Purwadi, 2011).

To cope with the competition in the banking world, Syari'ah banking continued to improve its quality, including better management. One important dimension plays an important role in the dynamics of organizational life is the human resource dimension. Sabran (2009), confirmed that one of the strategic stance in the dimensions of Human Resource is to develop Organizational Citizenship behavior employees in the organization. Organ (1988) suggested that Organizational Citizenship behavior attributes effectively financial and human resources, as well as assists organizational efficiency in operations. However, Organizational Citizenship behavior is voluntary, going beyond the influence of the formal incentive mechanism (Organ, 1990). Organizational Citizenship behavior cannot be spurred by formal rewards or incentives (Podsakoff and MacKenzie, 1997).

Generally, past studies of Organizational Citizenship behavior used procedural justice, organizational commitment, job satisfaction as antecedent variables (Moorman, et al. (1993). The emergence of employees' motivation to perform Organizational Citizenship behavior is because of organizational justice. Pillai, 1999 (in Sabran, 2009) found differences in the reward system will enhance the implementation of the role but differences award or reward opportunities would potentially make other people feel that justice / equality has been violated so they get a reward / recognition smaller impact on the Organizational Citizenship behavior. Fairness in the workplace can be a strong predictor for the manifestation of behavioral as research conducted by Moorman, et al. 
(1993), which states that justice organization that is measured in terms of procedural fairness effect on job satisfaction, organizational commitment and Organizational Citizenship behavior. Later studies conducted by Konovsky and Pugh's (1994), states that procedural justice affects Organizational Citizenship behavior through confidence in the leadership. Procedural justice significantly effects the organizational commitment (Gumusluoglu, Karakitapoglu, Hirst, 2012).

Organizational commitment is the willingness to exert extra effort for the organization's benefit, and a strong desire to maintain membership in the organization (Zeinabadi and Salehi (2011). Basically organizational commitment can be a predictor for Organizational Citizenship behavior as results from Zeinabadi and Salehi (2011), Moorman et al. (1993), which states that organizational commitment directly affects Organizational Citizenship behavior.

Job satisfaction according to Robbins (2006) is an attitude towards one's job, the difference between the amount of rewards that a worker received and a the amount of reward that they believe should be accepted. Podsakoff $e t$ al.(2006) revealed that employees who are satisfied generally easier to make contributions in excess of the role (Organizational Citizenship behavior) than others, such as the study conducted by Murphy, Athanasou, King (2002), that job satisfaction significantly influence Organizational Citizenship behavior.

Considering the important role played by the Islamic banking as an organization engaged in giving service, it is in need of professional employees who have competence in conducting basic tasks. Competence is now beginning to be used frequently to reflect a person's ability on the field - a particular field or particular skill, such as verbal communication, presentation skills, technical knowledge, stress control, planning ability and decision-making ability (Dreher, 2001). Therefore, it is necessary to improve career employees by tracking variables that determine the employees' satisfaction and performance. With their high performance, the employees will be able to improve their career. Hence, the leader needs stimulus to motivate his employees to perform Organizational Citizenship behavior, while the employees themselves intrinsically need to develop social exchange and the norm of responsibility that Islamic banking will come to compete and have a competitive advantage.

\section{Problem of the Study}

The low performance of the employee will have an impact on the poor performance of banks. One of the factors that can improve the performance of employees is Organizational Citizenship behavior. This gives motivation for the researchers to analyze and explain the important role of Organizational Citizenship behavior and its antecedence in improving the performance of employees in the organization.

\section{Purpose of the Study}

This study has six purposes: first, to identify the influence of procedural justice on Organizational Citizenship behavior employees of PT Bank Syariah in Malang; second, to identify the influence of the Organizational Citizenship behavior on Organizational Commitment; third, to identify the influence of employees Organizational Commitment to Performance; fourth, to identify the influence of job satisfaction on Organizational Citizenship behavior; fifth, to identify the influence of job satisfaction on employee performance; sixth, to identify the influence Organizational Citizenship behavior to employee's job performance.

\section{Literature Review}

\subsection{Procedural Justice}

Procedural fairness is part of an organizational justice that reflects the employees' appraisals toward the fairness of the process of making the results decisions (Greenberg, 1990 in Gumusluoglu, Karakitapoğlu, Hirst, 2012).

Procedural justice is the fairness perceived from the systems such as procedures used for the results and the allocation of resources (Leventhal, 1980; Lind \& Tyler, 1988; Moorman, 1991 in Gumusluoglu, Karakitapoğlu, Hirst, 2012).

\subsection{Organizational Commitment}

Luthans (2006) views commitment as an attitude that has a variety of definitions and broad measurement. Commitment is mostly defined as (1) a strong desire to remain a member of a particular organization, (2) the desire to strive as what organization desires (3) certain beliefs and acceptance of the value and purpose of the organization.

\subsubsection{Type of Commitment}

Organizational commitment is the level of trust and the acceptance of labor toward organizational goals and have a desire to remain within the organization. 
Meyer and Allen (1991) stated that organizational commitment is multi dimensional, hence, there are the developments of support from three dimensions of commitment, namely:

\section{- Affective Commitment}

Employee's emotional attachment, identification, and involvement in the organization.

\section{- $\quad$ Continuance Commitment}

Commitment based on losses related to discharge employees from the organization.

\section{- Normative Commitment}

Feeling of obligation to remain in the organization because it must be, so the action is the right thing to do.

\subsection{Job Satisfaction}

Robbins (1996) stated that job satisfaction refers to an individual's general attitude toward his work. A person with a high level of satisfaction, indicating a positive attitude towards work. Conversely, someone who is not satisfied with his work indicates a negative attitude towards work (Crossman, and Bassem, 2003). Job satisfaction is a positive emotion that results from feeling comfortable of every employee at the time of carrying out the work.

\subsubsection{Job Satisfaction Indicators}

Job satisfaction can be defined as a feeling of satisfaction or dissatisfaction with the work that has been done. In measuring job satisfaction, it is necessary to give indicators that can be used as a reference whether a person is satisfied or not satisfied at work. Luthan (2004) says there are several indicators of job satisfaction, among others:

\section{- $\quad$ The work itself}

Referring to how the work creates interesting tasks to the employees, opportunities for learning, and an opportunity to accept responsibility.

- The Conformity work with personality

Referring to the correspondence between perform and the personalities of the employees.

\section{- $\quad$ Pay and promotion}

Referring to the opportunity to gain promotion for a higher position and the compatibility between the amount of salaries / wages and the demands of the job.

- The attitude of coworkers', supervisors', employers'

Ability to interact with co-workers, boss or working environment. The relationships' level with co-workers and the level of support from co-workers in working situation and the support of supervisor.

- The conditions of working environment. The existence of safe working conditions, and conducive

\subsection{Organizational Citizenship Behavior}

Organizational Citizenship behavior, in the context of organizational theory by Organ, (2006) appears as a system of cooperation and people's willingness to contribute and to do some effort in a cooperative system and to be an absolute requirement in the organization.

Organ et al. (2006), Organ (1988), defines five major categories of Organizational Citizenship behavior, namely:

- Altruism

Discretionary behaviors that have the effect of helping a specific other person with an organizationally relevant task or problem.

\section{- Conscientiousness}

Discretioner behavior on the part of the employee that go well beyond the minimum role requirements of the organization, in the areas of attendance, obeying rules and regulations and so forth.

\section{- $\quad$ Sportmanship}

Willingness of the employee to tolerate less than ideal circumstances without complaining-to avoid complaining, railing against real or imagined slights.

\section{- Courtesy}

Discretionary behavior on the part of an individual aimed at preventing work related problems with others from occurring. 
- $\quad$ Civic virtue

Behavior on the part of an individual that indicates that he/she responsibly participates in, is involved in, or is concerned about the life of the company.

\subsection{Performance}

According to Kenerley and Neely (2002), performance measurement is defined as the process of quantifying the efficient and effectivity of actions. While the measurement of performance is defined as a metric used to quantify efficiently and effectively from an action.

\section{Research Questions and Hypothesis}

- Are procedural justice affects Organizational Citizenship behavior employees of PT Bank Syariah in Malang?

- Does the organization's commitment influence Organizational Citizenship behavior employees of PT Bank Syariah in Malang?

- Does the organization's commitment affect the performance of employees of PT Bank Syariah in Malang?

- Does the job satisfaction effect on Organizational Citizenship behavior employees of PT Bank Syariah in Malang?

- Does job satisfaction affects the performance of the employees of PT Bank Syariah in Malang?

- Does Organizational Citizenship behavior influence the performance of employees of PT Bank Syariah in Malang?

This study Attempts to test the following hypotheses:

- Procedural justice significantly effects on Organizational Citizenship behavior employees of PT Bank Syariah in Malang.

- Organizational Commitment significantly effects on Organizational Citizenship behavior employees of PT Bank Syariah in Malang.

- Organizational Commitment significantly effects on the performance of employees of PT Bank Syariah in Malang.

- Job satisfaction significantly influences Organizational Citizenship behavior employees of PT Bank Syariah in Malang.

- Job satisfaction significantly influences the performance of the employees of PT Bank Syariah in Malang.

- Organizational Citizenship behavior significantly affects the performance of the employees of PT Bank Syariah in Malang.

\section{Research Method}

This research is explanatory research. Explanatory research is to test the hypothesis between hypothesized variables.

\subsection{Population and Sample of Research}

In this study population was all Syariah Malang BTN employees, with 58 employees and PT Bank BRI Syariah employees as many as 225 employees. The total population is 283 employees.

Determination of respondent sample size was calculated using the formula T. Yamane (in Sani and Masyhuri, 2010), as follows:

Where:

$$
n=\frac{N}{N(d)^{2}+1}
$$

$\mathrm{n}=$ sample size

$\mathrm{N}=$ number of population

$\mathrm{d}=$ precision

so the number of samples obtained by 74 employees. All questionnaires were distributed, and 72 were return. Two questionnaires were eliminated because they were partially completed return. So the number of samples obtained by 70 employees. 


\subsection{Research Variables and Methods of Measuring}

This research studied the relationship between procedural justice, organizational commitment, job satisfaction, and Organizational Citizenship behavior and job performance from the point of view of Islamic Banking employees. In referencing exiting literature, the study established a basic research model. Figure 1 shows that procedural justice, organizational commitment, job satisfaction are independent variables; Job performance is the dependent variable; Organizational Citizenship behavior is the mediator variable. The study of data collected through questionnaires with six sections: procedural justice, organizational commitment, job satisfaction, Organizational Citizenship behavior, job performance, and basic respondent demographic data. The survey uses the fourth - point Likert scale, ranging from one (strongly disagree) to fourth (strongly agree).The 6-item scale procedural justice section is based on Colqiut (2001).The 10 - item scale based on job satisfaction section is based on Luthans (2004). The 12-item organizational commitment section based on Meyer dan Allen (1991). The Organizational Citizenship behavior scale was Adopted from Organ (1988). The 10-item scale measuring job performance used the studies by Sani (2011).

The questionnaires were formally issued from July to August 2012. All questionnaires were distributed, and 72 were return. Two questionnaires were eliminated because they were partially completed return.

\subsection{Method of Data Analysis and Testing Hypotheses}

For the purpose of statistical analysis and hypotheses testing, the researcher has employed the following methods: (1) Cronbach's alpha was calculated to confirm the reliability of each survey instrument. (2) Descriptive statistics (mean) was calculated for each variable. (3) Curve fit test was used to test linearity of variables. (4) GeSCA was used to test the model, as suggested by Tetenhaus (2008), Hwang (2009), Hwang et al (2010).

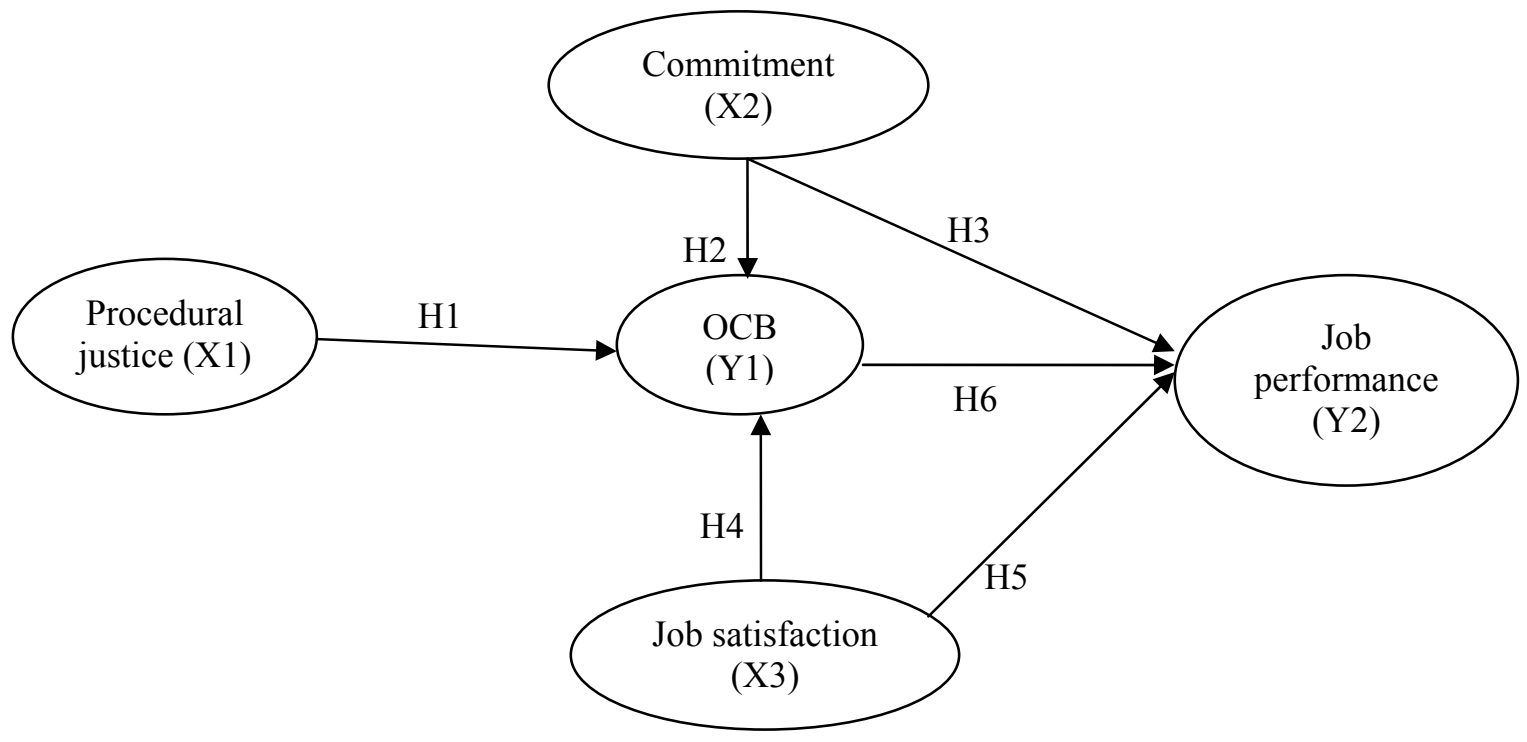

Figure 1. Research hypothesis model

\section{Finding and Discussion}

\subsection{Descriptive Statistics}

The population of the study consisted of the Syari'ah banking employees at Malang. The result in table (1) show that $66 \%$ of the sample were males, $34 \%$ were females. All of the respondents were between $\leq 30-\geq 40$ years old. 
Table 1. Characteristics of the sample

\begin{tabular}{cccc}
\hline Variables & Categories & Frequencies & Percentage (\%) \\
\hline Gender & Male & $46^{\text {th }}$ & $66^{\text {th }}$ \\
& Female & $24^{\text {th }}$ & $34^{\text {th }}$ \\
& Total & $70^{\text {th }}$ & 100.0 \\
\hline
\end{tabular}

The overall means of the responses are displayed in the table 2. It was found that all the means of (procedural justice) were above (2). The results indicated that the employees believe about procedural justice in their organization. It is too abvious from table 2 that all the means of the organizational commitment and job satisfaction were above 2 statements. While the results displayed in the table revealed that the OCB and job performance applied in a good degree. According to the respondents there is Altruism with a mean of 3.25; Civic virtue with a mean of 3.43; conscientiousness with a mean of 3.21; Courtesy with a mean of 3.59; Sportmanship with a mean of 3.75. Transaction management and administration with a mean of 3.12; customer oriented with a mean of 3.39; quality oriented with a mean of 3.16; team work with a mean of 3.23; Islamic and internalization with a mean of 3.38 .

Table 2. Descriptive statistics, means of responses

\begin{tabular}{|c|c|c|}
\hline Statement & & Mean \\
\hline & Procedural Justice & \\
\hline 1 & Performance appraisals & 2.29 \\
\hline 2 & Evaluation of achievement & 2.70 \\
\hline \multirow[t]{2}{*}{3} & Accuracy assessment & 2.96 \\
\hline & Satisfaction & \\
\hline 4 & Satisfied with the work itself & 2.09 \\
\hline 5 & Conformity work with personality & 2.36 \\
\hline 6 & Satisfied with the wages and Promotions & 2.45 \\
\hline 7 & Satisfied with coworkers, superiors & 2.54 \\
\hline \multirow[t]{2}{*}{8} & Satisfied with the working conditions & 2.93 \\
\hline & Organizational Commitment & \\
\hline 9 & Affective & 2.07 \\
\hline 10 th & Continuance & 2.32 \\
\hline \multirow[t]{2}{*}{11 th } & Normative & 2.68 \\
\hline & OCB & \\
\hline 12 th & Altruism & 3.25 \\
\hline 13th & Civic virtue & 3.43 \\
\hline 14 th & Conscientiousness & 3.21 \\
\hline 15 th & Courtesy & 3.59 \\
\hline \multirow[t]{2}{*}{ 16th } & Sportmanship & 3.75 \\
\hline & Employee performance & \\
\hline 17 th & Transaction management and administration & 3.12 \\
\hline $18^{\text {th }}$ & Focus on the customer & 3.39 \\
\hline $19^{\text {th }}$ & Quality orientation & 3.16 \\
\hline $20^{\text {th }}$ & Cooperation & 3.23 \\
\hline 21 & Internalizing values - the value of Syari'ah & 3.38 \\
\hline
\end{tabular}




\subsection{Testing Linearity Assumption}

Linear Test on the relationship between the variables in this study employs Curve Fit method. It is shown in the following table:

Table 3. Testing linearity assumption

\begin{tabular}{llccc}
\hline \multicolumn{2}{c}{ Interpersonal Variables } & Testing Results & Decision \\
\hline $\begin{array}{l}\text { Procedure Justice (X1) } \\
\text { Organizational }\end{array}$ & Commitment & OCB (Y1) & $0.000<0.05$ & Linear \\
$(\mathrm{X} 2)$ & OCB (Y1) & $0.000<0.05$ & Linear \\
Organizational & Commitment & Performance (Y2) & $0.000<0.05$ & Linear \\
$(\mathrm{X} 2)$ & OCB (Y1) & $0.021<0.05$ & Linear \\
Satisfaction (X3) & Performance (Y2) & $0.038<0.05$ & Linear \\
Satisfaction (X3) & Performance (Y2) & $0.000<0.05$ & Linear \\
OCB (Y1) & & & \\
\hline
\end{tabular}

The above table shows that all linear model is significant, so the assumption of linearity is met.

\subsection{Hypothesis Testing}

GeSCA is used to test the hypothesis with $p$ value $\leq 0.05$ significance level. Table 4 displayes the identification of goodness of fit.

Table 4. Identification of goodness of fit

\begin{tabular}{ccc}
\hline & Model Fit & \\
\hline FIT & 0436 \\
Afit & 0412 \\
GFI & 0981 \\
SRMR & 0157 \\
NPAR & 48 \\
\hline
\end{tabular}

From the table above, it can be seen that the value of FIT $=\mathbf{0 4 3 6}$, which means that the diversity of procedural justice, organizational commitment, job satisfaction, Organizational Citizenship behavior and employee performance which can be explained by the model is equal to $43.6 \%$; and the rest $(56.4 \%)$ can be explained by other variables.

\section{Afit Value $=0412$}

Afit (Adjusted FIT) is similar to the adjusted R squared regression analysis. Afit can be used for model comparison. Models with Afit greatest value can be chosen between better models. If seen from Afit, diversity of procedural justice, organizational commitment, job satisfaction, Organizational Citizenship behavior and employee performance that can be explained by the model is equal to $41.2 \%$, and the rest $(58.8 \%)$ can be explained by other variables.

\section{GFI}

In the literature it is said that a good value of GFI is approaching cut-off value of $\geq 0.90$, this GFI value is almost similar to the value of $\mathrm{R}$ square in regression. From the analysis, the value obtained GFI 0.981, indicating that the overall model is very good.

SRMR (Standardized Root Mean Square Residual)

In the literature it is said that a good SRMR value is close to the cut off value of 0 , the value is almost similar SRMR RMSEA value in SEM analysis.From the analysis, the SRMR value is obtained in 0.157 , indicating that the overall model is very good. 
Table 5. Result analysis GeSCA

\begin{tabular}{lccc}
\hline & Path Coefficients & & \\
\hline & Estimate & SE & CR \\
Procedural Justice -> OCB & 0519 & 0128 & $4.05^{*}$ \\
Commitment -> OCB & 0300 & 0118 & $2.54^{*}$ \\
Commitment -> Performance & 0615 & 0107 & $5.74^{*}$ \\
Satisfaction -> OCB & 0047 & 0103 & 0.45 \\
Satisfaction -> Performance & 0151 & 0117 & 1.28 \\
OCB -> Performance & 0269 & 0121 & $2.14^{*}$ \\
\hline
\end{tabular}

$\mathrm{CR} *=$ significant at.05 level.

GeSCA was used to test the hypothesis, with the significance level of $\leq 0.05$.Table 5 shows the results of path analysis.

H1: Procedural justice significantly influences Organizational Citizenship behavior employees of PT Bank Syariah in Malang.

For the results of a structural analysis of the model in the GSCA, the direct effect of procedural justice on Organizational Citizenship behavior is obtained with the value of 0.519 with $\mathrm{CR}$ value at $4.05>1.96$. Because $\mathrm{p}$-value $<5 \%$, then it is concluded that there is enough empirical evidence to accept the hypothesis that procedural justice directly influence Organizational Citizenship behavior. Because the path coefficient is positive (0.519), it indicates that the influence of both procedural justice and Organizational Citizenship behavior goes in the same direction. That means that the better procedural justice is, the better the level of employee Organizational Citizenship behavior will be.

H2: Organizational Commitment significanty effect Organizational Citizenship behavior employees of PT Bank Syariah in Malang.

From Table 5 above, the value of 0.300 is obtained with a value of $\mathrm{CR}$ at $2.54>1.96$. Because $\mathrm{p}$-value $<5 \%$, then it is conclude that there is enough empirical evidence to accept the hypothesis. Thus, organizational commitment directly influences Organizational Citizenship behavior. Because the path coefficient is positive (0.300), it indicates that the influence of both organizational commitment and Organizational Citizenship behavior goes in the same direction. That is, the better organizational commitment is, the better level of employee Organizational Citizenship behavior will be.

H3: Organizational Commitment significant effect on the performance of employees of PT Bank Syariah in Malang.

From the analysis of the direct influence of variable organizational commitment to employee performance, values is obtained at 0.615 with $\mathrm{CR}$ value of 5.74 $>1.96$. Because $\mathrm{p}$-value is at $<5 \%$, then there is enough empirical evidence to accept the hypothesis that organizational commitment directly affects employee performance. Because the path coefficient is positive (5.74), it indicates that the influence of both organizational commitment and performance of employees goes in the same the direction. That is, if the higher organizational commitment, the higher the employee performance will be.

H4: Job satisfaction significantly influence Organizational Citizenship behavior employees of PT Bank Syariah in Malang.

The results of a structural analysis of the model in the GSCA directly influence job satisfaction variable toward Organizational Citizenship behavior. The obtained values is 0.047 with the value of $\mathrm{CR}$ at $0.45<1.96$. Because $\mathrm{p}$-value is $>5 \%$, then there is not enough empirical evidence to accept the hypothesis that "job satisfaction directly influence Organizational Citizenship behavior". Although the path coefficient is positive (0.047) but considering $t$ count $<\mathrm{t}$ table, it indicates that both Job satisfaction and Organizational Citizenship behavior has no effect.

H5: Job satisfaction significantly influences the performance of the employees of PT Bank Syariah in Malang.

The results of the analysis of the variables directly influence job satisfaction on employee performance shows the values at 0.151 with a CR value of $1.28<1.96$. Because $p$-value is $>5 \%$, then there is not enough empirical 
evidence to accept the hypothesis that job satisfaction directly affects the performance of the employee. Although the path coefficient is positive $(0.151)$ but considering $t$ count $<t$ table, it indicates both Job satisfaction and the performance of the employees has no effect.

H6: Organizational Citizenship behavior significantly effects the performance of employees of PT Bank Syariah in Malang.

From the analysis of a structural model of the GSCA directly influences Organizational Citizenship behavior on employee performance variable, the obtained values are 0.269 with the value of $\mathrm{CR}$ at $2.14>1.96$. Because $\mathrm{p}$-value is $<5 \%$, then there is enough empirical evidence to accept the hypothesis that Organizational Citizenship behavior directly influences employee performance. Because the path coefficient is positive (0.269), it indicates that the influence of both Organizational Citizenship behavior and the performance of employees goes in the same the direction. That is, the higher Organizational Citizenship behavior is, the higher the employee performance will be.

\section{Conclusions and Recommendations}

The study aimed to examine, test and review the Organizational Citizenship behavior as mediating aspects on the influence of procedural justice, organizational commitment, job satisfaction on employee performance. The results showed that procedural justice affects Organizational Citizenship behavior. The results are consistent with research conducted by Zeinabadi and Salehi (2011), Greenberg (in Gumusluoglu, Karakitapoğlu, Hirst, 2012), (Leventhal, 1980; Lind \& Tyler, 1988; Moorman, 1991 in Gumusluoglu, Karakitapoğlu, Hirst, 2011). Thus, because the official procedures represent the organization to allocate resources; procedural justice tends to correlate with organization relating to the attitudes and behaviors.

The result implied that organizational commitment influenced Organizational Citizenship behavior. The results of this study support the previous research including the research conducted by Salehi and Gholtash (2011), (Mowday, Steers \& Porter, 1979; within Zeinabadi and Salehi (2011), Moorman, Niehoff and Organ (1993), which states that the organizational commitment directly influences the Organizational Citizenship behavior. Findings in the field also agree with the opinion of Robbins (2006) that see commitment as one of the working attitude, because it reflects the feelings of a person (likes or dislikest) to the organization where he workes.

Job satisfaction has no effect on Organizational Citizenship behavior Organizational Citizenship behavior. The results of the research support the research conducted by Kim, Sangmook (2006) that job satisfaction does not directly affect Organizational Citizenship behavior. Based on the interviews and supported by the respondents' answers to the open questionnaire, it is stated that working in Islamic banks is a kind of workship. In this case, the employees are required to work in every sincere. With a high sense of sincerity, each employee is capable of performing any work that he should handle.

Job satisfaction has no effect on performance. The findings in the field agrees with the theory advanced by Smith, et al (1969) in Gibson, et al (1996), Siagian (1989), that there are things that cause a comfort and satisfaction for someone in the workplace, among others: (1) a challenging job, (2) the application of a fair reward system, (3) supporting working conditions, and (4) the attitude of colleagues.

Organizational commitment affect performance. The results of this study support previous research including research conducted by Gunlu et al. (2010). Also supports the idea of Robbins (2004) that views commitment as one of the working attitude, as it reflects the feelings of a person (likes or dislikes) to the organization where he worked.

Organizational Citizenship behavior influences performance. The results of this study support previous research including research conducted by Chiang and Hsieh (2012), Podsakoff MacKenzei (2000), Organ (1998), Boerner, Eisenbeiss, Griesser (2007), stating that Organizational Citizenship behavior positively and significantly influences performance. It is expressed by Luthans (2004) that the organization citizenship behavior is positively associated with individual performance, group performance and organizational performance.

Based on the results of the study the researchers recommended that the leaders of Islamic banking, in particular the manager, supervisor, head of the unit need to think about factors that can increase employee commitment and Organizational Citizenship behavior, and to maintain the evaluation and assessment of employee performance.

\section{Limitation and Future Research}

This study is considered in expressing the impact of the procedural justice, organizational commitment, job satisfaction, Organizational Citizenship behavior on the job performance. But it has several limitations; namely: research design employed in this research is still not able to completely eliminate the possibility of common 
method bias, because all of the data used in the study was obtained from the self report. In addition, all data collected through self-report is also likely to be affected by response bias of social ddesirabilityy.It means that the given answers are considered appropriate but may not necessarily reflect the real situation.

For future research, the researchers suggest other research to perform different test between Organizational Citizenship behavior and performance of employees based on gender, education, years of service or to conduct research in all conventional banks in East Java, in order that the research carried can be more extensive and detailed.

\section{References}

Boerner, S. E., \& Griesser, E. (2007). Follower Behavior and Organizational Performance: The Impact of Transformational Leaders. Journal of Leadership and Organizational Studies, 13(3), 15-26. http://dx.doi.org/10.1177/10717919070130030201

Chun, C. F., \& Tsung, S. (2012). The Impacts of perceived organizational support and psychological empowerment on the job performance: the mediating effects of organizational citizenship behavior. International Journal of Hospitality Management, 31, 180-190. http://dx.doi.org/10.1016/j.ijhm.2011.04.011

Colquit, J. A. (2001). On the dimensionality of organizational justice: A construct validation of a measure. Journal of Applied Psychology, 86, 386-400. http://dx.doi.org/10.1037/0021-9010.86.3.386

Crossman, A., \& Bassem, A. Z. (2003). Job Satisfaction and Employee Performance of Lebanese Banking Staff. Journal of Managerial Psychology, 18(4), 368-376. http://dx.doi.org/10.1108/02683940310473118

Dreher. (2001). Human Resources Strategy, A Behavioral Perspective for the General Manager. Mc Graw Hill Internsational Edition.

Gibson, James, J. M., \& Donnelly, J. H. (1996). Organizational Behavior, Structure, Processes (8th ed.). Nunuk Adiarni translation. Binarupa script. Jakarta.

Gumusluoglu, L. K., \& Hirst, G. (2012). Transformational leadership and Rn d workers' multiple commitments: Do justice and span of control matter? Journal of Business Research, 30, 333.

Gunlu, E., A., \& Mehmet, S. P. (2010). Job satisfaction and organizational commitment of hotel managers in Turkey. International Journal of Contemporary Hospitaly Management, 22(5).

Hwang, H. (2009). Regularized Generalized Structured Component Analysis. Psychometrika, 70(3), 517-530. http://dx.doi.org/10.1007/s11336-009-9119-y

Hwang, H. N., Malholtra, Y., K., \& Hong, S., (2010). A Comparative study on Parameter recovery of three approaches to structural Equation Modeling. Journal of Marketing, 47(4), 669-712.

Kennerly, M., \& Neely, A. (2002). A Framework of the factors affecting The Evolustion of Performance Measurement system. The International Journal of Operation Production Management, 22(11), 1222-1245. http://dx.doi.org/10.1108/01443570210450293

Kim, S. (2006). Public service motivation and organizational citizenship behavior in Korea. International Journal of Manpower, 27(8), 722-740. http://dx.doi.org/10.1108/01437720610713521

Konovsky, M. A., \& Pugh, D. S. (1994). Citizenship behavior and social exchange. Academic of Management Journal, 37, 656-669. http://dx.doi.org/10.2307/256704

Luthan, F. (2004). Perilaku organisasi. Penerbit ANDI. Yogyakarta.

Meyer, J. P., \& Allen, M. J. (1991). A three component conseptualization of organizational commitment. Human Resources Management Review. http://dx.doi.org/10.1016/1053-4822(91)90011-Z

Moorman, R. H., Niehoff, B. P., \& Organ, D. W. (1993). Treating employees fairly and organizational citizenship behavior: sorting the effects of job satisfaction, organizational commitment and procedural justice. Employees Responsibilities and Rights Journal, 6, 209-225. http://dx.doi.org/10.1007/BF01419445

Murphy, G., Athanasou, J., \& King, N. (2002). Job satisfaction and organizational citizenship behavior. Journal of Managerial Psychology, 17(4), 287-297. http://dx.doi.org/10.1108/02683940210428092

Organ, D. W. (1998). Organizational citizenship behavior: The good soldier syndrome. Lexington, Lrxington, MA.

Organ, D. W. (1990). The motivational basis of organizational citizenship behavior. Organizational Behavior, 12, 
43-72.

Organ, W. D. (2006). Treating employees fairly and OCB: sorting the effect of job satisfaction, organizational commitment and procedural justice. Plenum Publishing Corporation: USA.

Podsakoff, P. M., \& MacKenzie, S. B. (1997). Impact of Organizational Citizenship on Organizational Performance: a Review and suggestion research. Human Performance, 10(2). 133-151. http://dx.doi.org/10.1207/s15327043hup1002_5

Podsakoff, P., MacKenzie, S., Paine, J., \& Bacharach, D. (2000), Organizational citizenship behaviors: a critical review of the theoretical and empirical literature and suggestions for future research. Journal of Management, 26(3), 513-63. http://dx.doi.org/10.1177/014920630002600307

Podsakoff, M. et al. (2006). Transformational leader behaviours and their effect on followers' trust in leader, satisfaction and OCB. Leadership $\quad$ Quarterly, $107-142$. http://dx.doi.org/10.1016/1048-9843(90)90009-7

Purwadi. (2011). Perkembangan Bank - Bank Syariah di Indonesia. Republika. Maret.

Robbins, S. (2006). Perilaku Organisasi: Konsep, Kontroversi Dan Aplikasi. Edisi Kedua. Terjemahan Pudjaatmaka. Prenhallindo. Jakarta.

Sabran. (2009). Pengaruh Kepemimpinan Transformasional, Keadilan Organisasional, Kepercayaan organisasional, kepuasan kerja terhadap OCB. Disertasi tidak dipublikasikan. Program Doktor Ilmu Manajemen, Unibraw.

Salehi, Moslem dan Abbas Gholtash. (2011). The relationship between job satisfaction, job burnout, and organizational commitment with organizational citizenship behavior among members of faculty in the islamic Azad University-first district branches, in order to provide the appropriate model. Procedia Social and Behavioral Sciences, 15, 306-310.

Sani Achmad Masyhuri. (2010). Riset Manajemen SDM. Edisi Pertama, Penerbit UIN Press Malang.

Sani, A. (2011). Pengaruh Kecerdasan Spiritual, Kecerdasan emosional, Kepemimpinan transformasional terhadap kepuasan dan kinerja manajer Bank syariah di Malang. Disertasi. PPSUB.

Siagian, P. S. (1989). Organisasi, Kepemimpinan dan Perilaku Administrasi. PT Gunung Agung. Jakarta.

Tenenhaus, M. (2008). Component based Structural Equation Modeling. Total Quality Management, 19(7-8), 871-886. http://dx.doi.org/10.1080/14783360802159543

Zeinabadi \& Salehi. (2011). Role of procedural justice, trust, job satisfaction, and organizational commitment in Organizational Citizenship behavior (OCB) of teachers: proposing a modified social exchange model. Procedia-Social and Behavioral Sciences, 29, 1472-1481. http://dx.doi.org/10.1016/j.sbspro.2011.11.387

\section{Copyrights}

Copyright for this article is retained by the author(s), with first publication rights granted to the journal.

This is an open-access article distributed under the terms and conditions of the Creative Commons Attribution license (http://creativecommons.org/licenses/by/3.0/). 